\title{
PERAN PSIKOEDUKASI TENTANG MOTIVASI TERHADAP KESADARAN BERPRESTASI SISWA DI PESANTREN
}

\author{
Hartini Laswandi \\ Jurusan Desain, Universitas Tarumanagara Jakarta \\ Email: hartini@fsrd.untar.ac.id
}

\begin{abstract}
Lack of awareness of achievement is one of the problems that are often found in students today. At the high school or Islamic boarding school level students, the group that lacks an understanding of motivation is higher than in universities, solutions that can be done to reduce the prevalence of lack of motivation, one of which can be done with psychoeducation. Psychoeducation is an action given to individuals in a special way in overcoming psychosocial problems experienced by students. The knowledge that is grown through psychoeducation will be able to influence the beliefs of students who previously had less motivation in achievement awareness to become more enthusiastic so that it will bring up strong intentions or intentions to excel in realizing their goals. This study aims to determine the effect of psychoeducation about motivation on student achievement awareness in Islamic boarding schools, to determine the relationship between teacher efforts in motivating student learning and achievement awareness, especially in realizing their goals. The method used in this research is a motivational tutorial and a survey on the motivation of Islamic boarding school students. A sample of 75 students was selected using a combination of random and proportional techniques. Data collection was carried out using a questionnaire, namely using a Likert scale and using text in multiple choice questions. Students were asked to fill out questionnaires which were distributed pre-test and post-test. Questions for learning interest questionnaires and questions for learning motivation. After being analyzed, it is found that the better the perception of the teacher's efforts in motivating student learning, the better the student's learning achievement. This research was conducted with a sample of class XI and X students at the At-Taqwa Islamic boarding school in Tangerang.
\end{abstract}

Keywords: Psychoeducation, Motivation, Achievement Awareness

Kurangnya kesadaran berprestasi merupakan salah satu masalah yang banyak dijumpai pada siswa saat ini. Pada pelajar tingkat SMA atau pesantren (studi kasus Pesantren At-Taqwa), kelompok yang kurang pemahaman tentang motifasi lebih tinggi dibandingkan perguruan tinggi, solusi yang dapat dilakukan untuk mengurangi angka prevalensi kurangnya motifasi, salah satunya dapat dilakukan dengan psikoedukasi. Psikoedukasi merupakan suatu tindakan yang diberikan kepada individu dengan cara khusus dalam mengatasi permasalahan psikososial yang dialami oleh siswa. Pengetahuan yang ditumbuhkan melalui psikoedukasi akan dapat mempengaruhi keyakinan siswa yang tadinya mempunyai motivasi yang kurang dalam kesadaran berprestasi menjadi lebih bersemangat sehingga akan memunculkan intensi atau niat yang kuat untuk berprestasi dalam mewujudkan cita-citanya. Penelitian ini bertujuan untuk mengetahui pengaruh psikoedukasi Tentang Motivasi Terhadap Kesadaran Berprestasi Siswa di Pesantren, mengetahui hubungan antara upaya guru dalam memotivasi belajar siswa terhadap kesadaran berprestasi, terutama dalam mewujudkan cita-cita mereka. Metode yang digunakan dalam penelitian ini adalah tutorial memotivasi serta survei tentang motivasi siswa pesantren. Sampel berjumlah 75 siswa yamg dipilih dengan teknik gabungan antara acak dan proporsional. Pengumpulan data dilaksanakan dengan menggunakn kuesioner, yaitu denagan skala Likert dan menggunakan teks dalam soal pilihan ganda. Siswa diminta mengisi kuisioner yang dibagikan secara pre tes dan post tes. Soal untuk kuesioner minat belajar dan soal untuk motivasi belajar. Setelah dianalisis maka dihasilkan bahwa semakin baik persepsi atas upaya guru dalam memotivasi belajar siswa diikuti oleh semakin baiknya prestasi belajar siswa. Penelitian ini dilakukan dengan sampel siswa kelas XI dan X sekolah pesantren At-Taqwa di Tangerang.

Kata Kunci: Psikoedukasi, Motivasi, kesadaran berprestasi

\section{PENDAHULUAN}

Pandemi Covid-19 yang dialami seluruh dunia sejak akhir tahun 2019 mengakibatkan banyak sekolah tutup. Selama masa pandemi ini di sekolah menengah khususnya sekolah pesantren, 
motivasi jarang diperhatikan dan dianggap sebagai hal yang biasa. Padahal motivasi tersebut merupakan permasalahan penting di kalangan pelajar saat usia remaja ini. Ada beberapa faktor yang menjadi hambatan dalam permasalahan tersebut yaitu diantaranya faktor internal dan faktor eksternal. Faktor internal meliputi biologis (fisik dan kesehatan), minat, perhatian, dan intelegensi siswa. Untuk faktor eksternal meliputi guru, teman, cara pengajaran, peran orang tua dan keluarga serta lingkungan. Ditinjau berdasarkan pembentukannya, motivasi dapat dibedakan menjadi 2 jenis, yakni: Pertama, motif-motif bawaan, yaitu motif yang dibawa sejak lahir, tanpa dipelajari. Motif ini sering disebut motif yang diisyaratkan secara biologis. Arden N. Frandsen memberi istilah Physiologicaldrive. Kedua, motif-motif yang dipelajari, yaitu motif yang timbul karena dipelajari. Motif ini sering disebut motif yang diisyaratkan secara sosial. Arden N. Frandsen memberi istilah affiliativeneed, Sardiman, AM (2009)

Satu diantara faktor penghambat belajar pada siswa adalah minat dan motivasi siswa tersebut dalam mempelajari materi-materi pelajaran. Hambatan ini termasuk dalam faktor internal. Motivasi adalah apa yang membuat seseorang berbuat, membuat seseorang tetap berbuat dan menentukan ke arah mana yang hendak orang tersebut perbuat. Siswa akan berusaha mencapai suatu tujuan karena dirangsang oleh manfaat atau keuntungan yang akan diperoleh. Kurangnya motivasi pada diri siswa menyebabkan seorang siswa tidak sungguh-sungguh atau kurang bersemangat dalam melaksanakan kegiatan sehingga terhambat dalam mencapai tujuan belajar. Apabila siswa saat kondisi pandemik ini tidak termotivasi maka siswa akan malas untuk memperhatikan pelajaran yang disampaikan oleh guru, siswa tidak akan tertarik untuk melakukan kegiatan di pesantren, mengajukan pertanyaan kepada guru terhadap hal-hal yang belum jelas bahkan siswa akan kurang giat belajar agar mendapatkan nilai yang baik dalam mata pelajaran yang diikutinya. Tinggi rendahnya motivasi selalu dijadikan indikator terhadap baik buruknya prestasi belajar peserta didik, Yohanes Joko Saptono (2016).

Motivasi dapat berupa berbagai macam bentuk kegiatan. Permasalahan yang terjadi di kalangan Pesantren At-Taqwa di Tangerang adalah tidak adanya pihak yang memberikan pengertian terkait pentingnya motivasi dan manfaat memotivasi kepada siswa di pesantren. Hal tersebut ditunjukkan dengan perilaku kebingungan dalam mengarahkan dalam meraih prestasi yang mereka tetapkan, tidak ada dorongan untuk berusaha mencapai keunggulan dan kesuksesan. Motivasi belajar siswa dan kompetensi guru memiliki pengaruh positif dan signifikan baik secara parsial maupun simultan terhadap prestasi belajar siswa, Elis Mediawati, (2010).

Dari uraian tersebut, untuk menumbuhkan motivasi belajar, perlu adanya pemahaman kepada siswa maupun guru-gurunya terkait motivasi dan bagaimana memotivasi belajar. Pemahaman tersebut diharapkan dapat membangkitkan motivasi mereka secara intrinsik amupun ekstrinsik sehingga siswa dapat termotivasi dan lebih terdorong untuk terus berprestasi mencapai keunggulan dan kesuksesan. Pentingnya motivasi belajar ditegaskan oleh Amna Emda (2017) yang menyatakan bahwa motivasi berfungsi untuk menyadarkan kedudukan awal belajar, proses dan hasil akhir.

Peranan informasi tentang motivasi dapat memberikan pemahaman kepada pengguna sekolah, yaitu berupa fakta, konsep, dan prinsip tertentu. Menumbuhkan motivasi belajar siswa merupakan salah satu teknik dalam mengembangkan kemampuan dan kemauan belajar.Proses memahami menurut, Siti Suprihatin, (2015) yaitu: (1) menginterpretasikan atau menafsirkan; (2) memberikan contoh; (3) mengklasifikasikan; (4) merangkum; (5) menyimpulkan; (6) membandingkan; (7) menjelaskan. Kegiatan sosialisasi banyak menjadi inspirasi untuk menjelaskan suatu data yang panjang menjadi bahasa penyampaian secara langsung dan jelas. Emria Fitri, Neviyarni, Ifdil (2016). 


\section{METODE PELAKSANAAN PKM}

Desain penelitian pada penelitian ini menggunakan jenis penelitian Quasi experiment dengan one group pre-test dan posttest design. Variabel yang digunakan dalam penelitian ini terdapat dua yakni, psikoedukasi menjadi bebas dan pengetahuan, motivasi dan perilaku menjadi terikat. Penelitian dilaksanakan pada Agustus 2020 dengan pendekatan yang berangkat dari masalah pada Pesantren At-Taqwa Tangerang tentang pengetahuan motivasi yang tidak dimiliki guru dan murid. Kegiatan ini mencakup dua tahap, yaitu tahapan identifikasi masalah dan penyusunan konsep.

Tahapan kegiatan mencakup proses pengumpulan data hingga analisis data. Pengumpulan data dilakukan dengan studi literatur, observasi dan wawancara dengan narasumber. Narasumber terdiri atas kepala pesantren dan siwa. Hasil pengumpulan data kemudian dianalisis untuk dijadikan dasar acuan dalam proses kegiatan motivasi. Data terkait pemahaman terhadap motivasi yang dihasilkan, dianalisis sehingga didapatkan konsep. Tahapan diskripsi konsep peran motivasi terhadap kesadaran berprestasi, dan bagaimana mengoptimalkan prestasi siswa menjadi yang terdepan.

\section{HASIL DAN PEMBAHASAN}

\section{Pernyataan motivasi berprestasi responden}

Pernyataan Motivasi Berprestasi Responden dalam penelitian ini didasarkan atas pengenalan motivasi, sejauh mana pemahaman terhadap motivasi, pemahaman aspek-aspek motivasi dan tanggungjawab. Pernyataan Motivasi Berprestasi responden diidentifikasi berdasarkan angket dan total sampel dalam penelitian, yakni 48 responden. Hasil analisis statistik deskriptif untuk karakteristik responden disajikan sebagai berikut:

Pre-test: Uji hipotesa variabel tidak semangat akan pengejaran prestasi dengan motivasi belajar menunjukkan bahwa, tidak ada hubungan antara tidak semangat dengan motivasi belajar pada siswa di pesantren. Dengan demikian hipotesis minor pertama dalam artikel ini yaitu terdapat hubungan antara tidak semangat akan menyebabkan kegagalan dengan motivasi belajar siswa di pesantren ditolak. Uji hipotesa dukungan orangtua dan guru dengan motivasi belajar menunjukkan koefisien korelasi antara kedua variabel. Semakin tinggi dukungan guru dan orangtua, maka semakin tinggi motivasi belajar. Hal ini berarti ada hubungan antara dukungan guru dan orangtua dengan motivasi belajar siswa di pesantren. Dengan demikian hipotesis minor kedua yaitu terdapat hubungan antara dukungan guru dan orangtua dengan motivasi belajar siswa di pesantren diterima. Hal ini diketahui dari hasil respon subjek pada item dalam skala yang menunjukkan prosentase motivasi belajar siswa yang berada di pesantren At-Taqwa. Siswa yang memiliki Motivasi belajar kategori sangat tinggi memiliki prosentase paling rendah, tingkat motivasi belajar dalam kategori tinggi urutan prosentase sedang, tingkat motivasi belajar dalam kategori sedang merupakan prosentase tertinggi, tingkat motivasi belajar dalam kategori rendah urutan prosentase sedang, dan tingkat motivasi belajar dalam kategori sangat rendah prosentase rendah.

Hasil analisis variabel tidak adanya pemahaman, tidak adanya dorongan meraih prestasi atau menjadi yang terdepan terlihat dari angket yang diberikan. Hal ini diketahui dari hasil respon subyek pada item dalam skala yang menunjukkan prosentase tidak adanya pemahaman, tidak adanya dorongan meraih prestasi atau menjadi yang terdepan siswa yang berada di pesantren At-Taqwa. Hasil analisis variabel dukungan guru dan orangtua juga merupakan alasan siswa kurang termotivasi. Kurang pahamnya terhadap peran motivasi pada siswa yang berada di pondok pesantren At-Taqwa tergolong tinggi. Hal ini diketahui dari hasil respon subyek pada instrumen yang diberikan. 


\section{Implementasi psikoedukasi memotivasi siswa}

Berdasarkan analisis data, hipotesis yang diajukan yaitu ada hubungan positif antara pemahaman terhapad motivasi dan dorongan meraih prestasi atau menjadi yang terdepan pada siswa di pesantren At-Taqwa, maka hipotesis yang diajukan diterima bahwa ada hubungan positif yang sangat signifikan antara pemahaman terhapad motivasi dan dorongan meraih prestasi atau menjadi yang terdepan akan kegagalan dan dukungan guru dengan motivasi belajar siswa yang berada di pondok pesantren At-Taqwa Tangerang. Artinya semakin tinggi pemahaman terhapad motivasi dan dorongan meraih prestasi atau menjadi yang terdepan, maka semakin tinggi pula motivasi belajar. Semakin rendah pemahaman terhapad motivasi dan dorongan meraih prestasi atau menjadi yang terdepan, maka semakin rendah motivasi belajar. Sumbangan efektif variabel pemahaman terhapad motivasi dan dorongan meraih prestasi atau menjadi yang terdepan dengan motivasi belajar siswa akan mempengaruhi motivasi belajar.

Pentingnya motivasi belajar untuk menyadarkan kedudukan awal belajar, proses dan hasil akhir, menginformasikan tentang kekuatan usaha belajar yang dibandingkan dengan teman sebaya, mengarahkan kegiatan belajar, membesarkan atau mendorong, menyadarkan tentang adanya perjalanan belajar dan kemudian berprofesi. Salah satu faktor yang mempengaruhi motivasi belajar adalah pemahaman terhapad motivasi dan dorongan meraih prestasi atau menjadi yang terdepan..

Kegiatan pemahaman terhadap pentingnya pemahaman terhapad motivasi dan dorongan meraih prestasi atau menjadi yang terdepan, dapat dilihat pada foto-foto di bawah ini (foto 1 , $2,3,4)$;
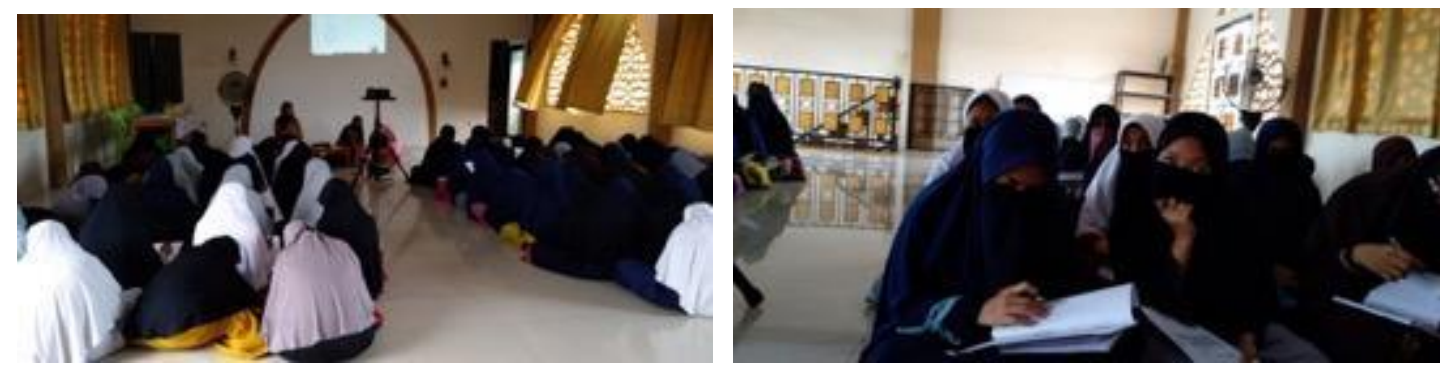

Gambar 1

Kegiatan pemahaman pentingnya motivasi
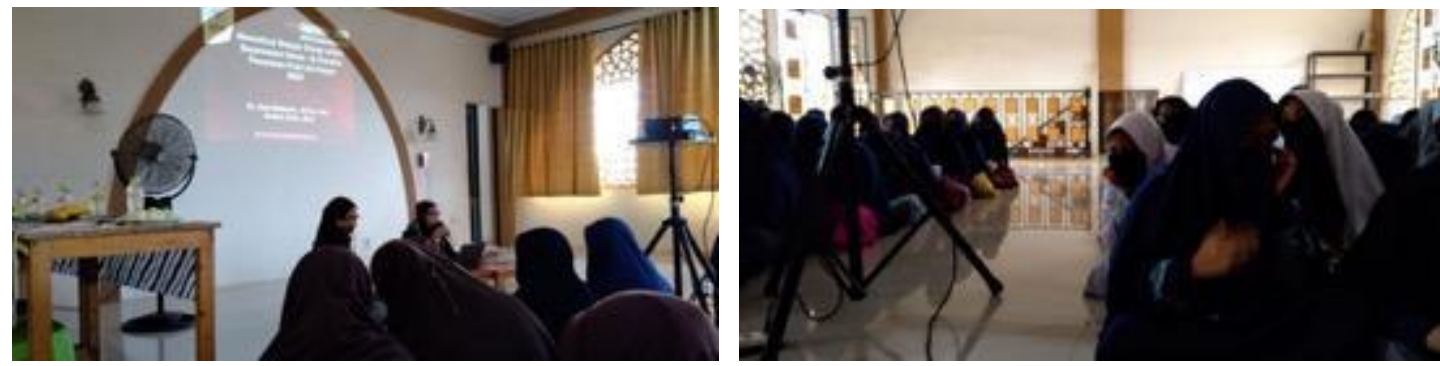

Gambar 2

Siswa pesantren At-Taqwa saat mengikuti spikoedukasi tentang motivasi 

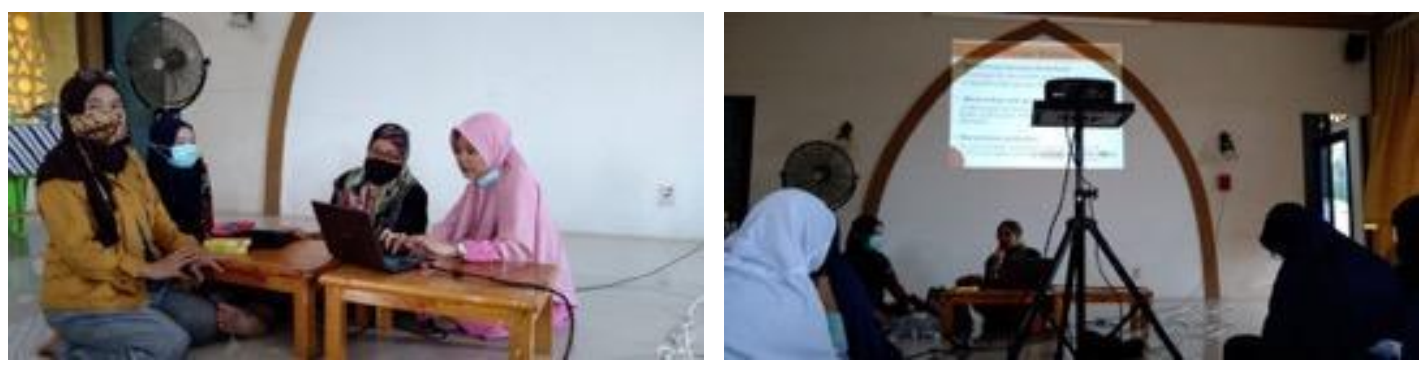

Gambar 3

Kegiatan pemahaman pentingnya motivasi

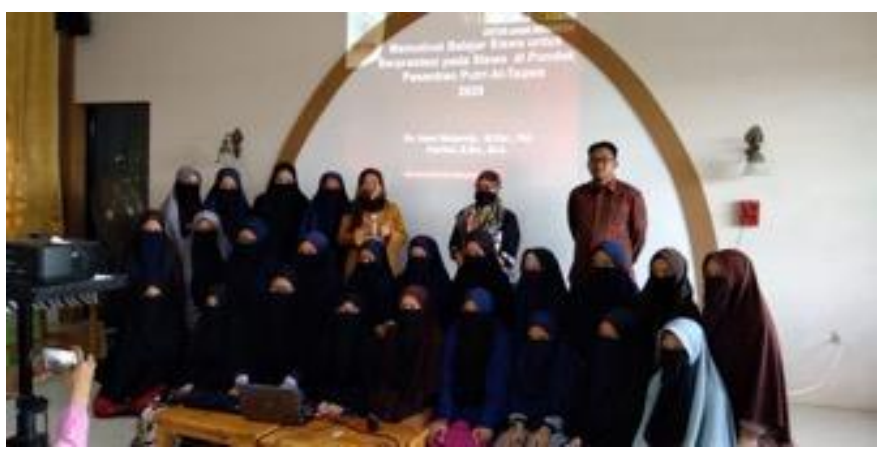

Gambar 4

Team bersama siswa dan kepala sekolah dalam kegiatan psikoedukasi pentingnya motivasi

\section{KESIMPULAN DAN SARAN}

Kegiatan Psikoedukasi mempengaruhi pengetahuan, motivasi dan perubahan prilaku terhadap kesadaran berprestasi pada siswa SMA atau pesantren dalam menyikapi kurangnya kesadaran berprestasi lebih gigih lagi menjadi yang terdepan.

Pentingnya memotivasi belajar secara pemahaman dan tindakan untuk siswa di pesantren, yang berupa pemberian informasi terkait pentingnya motivasi dalam belajar dalam mendorong meraih prestasi atau menjadi yang terdepan. Spesifikasi luaran kegiatan berupa pemberian peningkatan pemahaman informasi tentang motivasi dan hal-hal yang meningkatkan motivasi. Luaran yang dicapai target pertama: gutu di pesantren memahami pentingnya memberikan pemahaman tentang motivasi dalam belajar dalam mendorong meraih prestasi atau menjadi yang terdepan. Target kedua: siswa memperoleh pemahaman pentingnya motivasi, dan hal-hal apa saja yang bisa meningkatkan motivasi dalam belajar. Target Ketiga: siswa di pesantren dapat mengatasi dan mencari solusi apabila motivasi belajar mereka menurun maka apa yang perlu dilakukan untuk membangkitkan kembali motivasi belajarnya.

\section{Ucapan Terima Kasih}

Kami penulis artikel ini mengucapkan terima kasih kepada LPPI Untar yang telah memfsilitasi dan mensuport dalam kegiatan ini. 


\section{REFERENSI}

Amna Emda, (2017), Kedudukan Motivasi Belajar Siswa Dalam Pembelajaran , Lantanida Journal, Vol. 5 No. 2 (2017) 93-196, Fakultas Tarbiyah dan Keguruan UIN Ar-Raniry Banda Aceh

Elis Mediawati, (2010), Pengaruh Motivasi Belajar Mahasiswa Dan Kompetensi Dosen Terhadap Prestasi Belajar, Jurnal Pendidikan Ekonomi Dinamika Pendidikan, Vol. V, No. 2, Desember 2010. Hal. 134 - 146

Emria Fitri, Neviyarni, Ifdil (2016), Efektivitas Layanan Informasi Dengan Menggunakan Metode Blended Learning Untuk Meningkatkan Motivasi Belajar, Jurnal Psikologi Pendidikan \& Konseling, Volume 2 Nomor 2 Juni 2016. Hal 84-92p-ISSN: 2443-2202 e-ISSN: 2477-2518, Homepage: http://ojs.unm.ac.id/index.php/JPPK

Permata, VDB, Dewi Martha Indra, Marindra Firmansyah, (2020), Pengaruh Psikoedukasi Pencegahan Penyalahgunaan Narkoba Terhadap Pengetahuan, Motivasi da Perilaku Pada Siswa SMA, Jurnal Kedokteran Komunitas, ISSN : 2337-6988 http://riset.unisma.ac.id/index.php/jkkfk/article/view/7980

Sardiman, AM. Interaksi dan Motivasi Belajar Mengajar, Jakarta: Rajawali Pers, 2009

Siti Suprihatin, (2015), Upaya Guru Dalam Meningkatkan Motivasi Belajar Siswa, Jurnal Pendidikan Ekonomi UM Metro ISSN: 2442-9449 Vol.3.No.1 (2015) 73-82. Jurnal Promosi 73. Pendidikan Ekonomi FKIP Universitas Muhammadiyah Metro

Yohanes Joko Saptono (2016), Motivasi Dan Keberhasilan Belajar Siswa, Jurnal Pendidikan Agama Kristen, Vol 1 Nomor 1, ISSN 2502-8030 